\title{
Histamine Inhibits the Production of Interleukin-12 through Interaction with $\mathrm{H}_{2}$ Receptors
}

\author{
Tineke C.T.M. van der Pouw Kraan, ${ }^{\star}$ Alies Snijders, ${ }^{\ddagger}$ Leonie C.M. Boeije, ${ }^{\star}$ Els R. de Groot, ${ }^{\star}$ Astrid E. Alewijnse, ${ }^{\S}$ \\ Rob Leurs, ${ }^{\S}$ and Lucien A. Aarden* \\ *CLB, Sanquin Blood Supply Foundation, Department of Auto-Immune Diseases, Laboratory for Experimental and Clinical \\ Immunology, Academic Medical Centre, University of Amsterdam, 1066CX Amsterdam, The Netherlands; ${ }^{\ddagger}$ Laboratory of Cell Biology \\ and Histology, Academic Medical Centre, 1105 AZ Amsterdam, The Netherlands; and ${ }^{\S}$ Department of Pharmacochemistry, Free \\ University, Leiden/Amsterdam Centre for Drug Research, 1081 HV Amsterdam, The Netherlands
}

\begin{abstract}
IL-12 is essential for T helper 1 (Th1) development and inhibits the induction of Th2 responses. Atopic diseases, which are characterized by $\mathrm{Th} 2$ responses, are associated with the overproduction of histamine. Here we present evidence that histamine, at physiological concentrations, strongly inhibits human IL-12 p40 and p70 mRNA and protein production by human monocytes. The use of specific histamine receptor antagonists reveals that this inhibition is mediated via the $\mathrm{H}_{2}$ receptor and induction of intracellular cAMP. The inhibition of IL-12 production is independent of IL-10 and IFN- $\gamma$. The observation that histamine strongly reduces the production of the Th1-inducing cytokine IL-12 implies a positive feedback mechanism for the development of Th2 responses in atopic patients. (J. Clin. Invest. 1998. 102:1866-1873.) Key words: cytokines • allergy and immunology • Th1 cells $\bullet$ monocytes $\bullet$ interferon gamma
\end{abstract}

\section{Introduction}

Two distinct subsets of $\mathrm{CD}^{+}{ }^{+} \mathrm{T}$ helper $(\mathrm{Th})^{1}$ cells with different cytokine profiles and functions have been shown to develop from naive precursors. Th1 cells produce IL-2, IFN- $\gamma$, and TNF- $\beta$, activate macrophages, and cause delayed type hypersensitivity reactions, whereas Th2 cells produce IL-4, IL-5, IL-10, and IL-13, cause eosinophilia, and induce an immunoglobulin class switch to IgG1 (mouse) or IgG4 (human) and $\operatorname{IgE}(1-3)$. Aberrant regulation of Th1 or Th2 responses leads to immunopathology; in patients with HIV infection and allergic patients, $\mathrm{T}$ helper cells are believed to have shifted toward

Address correspondence to Tineke C.T.M. van der Pouw Kraan, CLB, Sanquin Blood Supply Foundation, Department of AutoImmune Diseases, Plesmanlaan 125, 1066 CX Amsterdam, The Netherlands. Phone: 31-20-512-3171; FAX: 31-20-512-3170; E-mail: TpouwK@CLB.nl

Received for publication 10 April 1998 and accepted in revised form 14 September 1998.

1. Abbreviations used in this paper: $\beta 2-\mathrm{M}, \beta 2$-microglobulin; CRE, cAMP responsive element; DTH, delayed-type hypersensitivity; ICER, inducible cAMP early repressor; $\mathrm{PGE}_{2}$, prostaglandin $\mathrm{E}_{2}$; RT, reverse transcriptase; SAC, Staphylococcus aureus Cowan I strain; Th1, T helper 1 cell.

J. Clin. Invest.

(C) The American Society for Clinical Investigation, Inc. 0021-9738/98/11/1866/08 \$2.00

Volume 102, Number 10, November 1998, 1866-1873

http://www.jci.org a Th2 response (4-6), while various organ-specific autoimmune diseases are characterized by Th1-like responses (7).

Recently, it has become clear that the APC-derived factor IL-12 is instrumental for development of a Th1 response (8). Only the IL-12 p70 heterodimer, consisting of a p40 and p35 chain, encoded by two separate genes, is biologically active (9). No biological function is known for the single p40 chain, which is secreted in excess over the p70 protein. IL-12 induces proliferation and IFN- $\gamma$ production and enhances cytolytic activity in T cells and NK cells $(10,11)$. In contrast, in the absence of IL-12, a Th2 response is able to develop $(8,12)$. Therefore, modulation of IL-12 production during an immune response is crucial for the outcome of disease. The Th1 product IFN- $\gamma$ provides a positive feedback on Th1 development by its capacity to strongly upregulate the production of IL-12 by monocytes (13-15). Endogenous inhibitors of human IL-12 production are IL-10, IL-4, IL-13, and TGF- $\beta(16,17)$ and members of the complement system. Ligation of $\mathrm{iC} 3 \mathrm{~b}$ with complement receptor 3 and cross-linking of CD46 by $\mathrm{C} 3 \mathrm{~b}$ or measles virus also inhibits the production of IL-12 $(18,19)$. We previously stated that cAMP-inducing agents such as prostaglandin $\mathrm{E}_{2}$ $\left(\mathrm{PGE}_{2}\right)$ are strong inhibitors of IL-12 p40 production, while upregulating IL-10 production in LPS-stimulated human monocytes (20). Thereafter, it was reported that $\beta_{2}$ agonists also inhibited human IL-12 production and Th1 development by increasing intracellular cAMP (21).

Histamine is an endogenous mediator of many (patho)physiological processes, such as the regulation of gastric acid secretion and cardiac output, while functioning as a neurotransmitter in the brain (for reviews see references 22 and 23). During allergic reactions, histamine is released in large quantities from intracellular stores from mast cells and basophils after cross-linking of cell surface IgE by allergens. Based on the activity of various selective agonists and antagonists, three types of histamine receptors have been described, designated $\mathrm{H}_{1}, \mathrm{H}_{2}$, and $\mathrm{H}_{3}$. Signaling through the $\mathrm{H}_{1}$ receptor involves the activation of PLC, leading to the generation of 1,4,5-inositol phosphate and DAG, whereas $\mathrm{H}_{2}$ receptor stimulation results in cAMP generation $(22,23)$. $\mathrm{H}_{1}$ and $\mathrm{H}_{2}$ receptors are expressed on many cell types, including lymphoid cells (24-26). The immune modulating effects of histamine include inhibition of IL- 2 and IFN- $\gamma$ production by T cells and inhibition of TNF- $\alpha$ and IL-1 production by monocytes (27-29). Less is known about the $\mathrm{H}_{3}$ receptor; its expression is observed in the brain (in addition to $\mathrm{H}_{1}$ and $\mathrm{H}_{2}$ receptors), but on lymphoid cells its expression is not well studied. Indirect evidence indicates the presence of $\mathrm{H}_{3}$ receptors on eosinophils (30). The signaling pathway of this receptor is largely unknown. In the present study, we report that $\mathrm{H}_{2}$ receptor stimulation inhibits IL-12 production by monocytes. This observation leads to new 
concepts on the role of histamine during allergic reactions and $\mathrm{T}$ helper development.

\section{Methods}

\section{Antibodies and reagents}

The anti-IL-12 mAbs, reacting with both IL-12 p40 and p70, C11.79 and C8.6 (31), were kindly provided by Dr. G. Trinchieri (The Wistar Institute, Philadelphia, PA). mAb 20C2, specific for IL-12 p70, was a kind gift from Dr. M.K. Gately (Hoffmann-LaRoche, Nutley, NJ). Anti-IL-10 mAb B-T10 and B-N10 were a kind gift from Dr. J. Wijdenes (Diaclone, Besancon, France). $\mathrm{PGE}_{2}$ was obtained from Sigma Chemical Co. (St. Louis, MO). rhIL-10 was a kind gift from Dr. R. de Waal Malefijt (DNAX, Palo Alto, CA). Staphylococcus aureus Cowan I strain (SAC, Pansorbin) was obtained from Calbiochem (La Jolla, CA), histamine dihydrochloride and triprolidine dihydrochloride from Sigma Chemical Co., and ranitidine dihydrochloride from Glaxo (Middlesex, UK). Clobenpropit dihydrobromide and amthamine dihydrobromide were synthesized at the Free University (Department of Pharmacochemistry, Amsterdam, The Netherlands).

\section{Whole blood cultures}

Whole blood was obtained by venepuncture from normal healthy donors in sodium-heparin-containing sterile blood collecting tubes (VT-100SH tubes, Venoject; Terumo Europe N.V., Leuven, Belgium). To prevent spontaneous production of cytokines by endotoxin or endotoxin-like substances present in culture media, IMDM was ultrafiltrated by means of a hollow-fiber dialyzer (32) (Hemoflow F5; Fresenius A.G., Bad Homburg, Germany). Whole blood was diluted 1:10 in ultrafiltrated IMDM, supplemented with $0.1 \%$ FCS, penicillin $(100 \mathrm{IU} / \mathrm{ml})$, streptomycin $(100 \mu \mathrm{g} / \mathrm{ml})$, and $15 \mathrm{IU} / \mathrm{ml}$ sodium heparin (Leo Pharmaceutical Products B.V., Weesp, The Netherlands). Diluted whole blood was cultured in triplicate in $200-\mu$ l flat-bottomed culture plates (Nunc, Roskilde, Denmark) and stimulated with SAC $(0.01 \% \mathrm{wt} / \mathrm{vol})$. Histamine, agonist, antagonists, or $\mathrm{PGE}_{2}$ were added simultaneously with SAC. Supernatants were harvested after 18-24 h of culture, and cytokine levels were determined.

\section{Assays for cytokines}

IL-12 p70 ELISA. Flat-bottomed microtiter plates (Maxisorb; Nunc) were coated overnight with $\mathrm{mAb} 20 \mathrm{C} 2(0.5 \mu \mathrm{g} / \mathrm{ml}$ in $0.1 \mathrm{M}$ carbonate buffer, $\mathrm{pH} 9.6,100 \mu \mathrm{l} /$ well). All subsequent incubations were in 100$\mu \mathrm{l}$ volumes at room temperature. The plates were washed twice with PBS, $0.02 \%$ (vol $/ \mathrm{vol}$ ) Tween 20, and incubated for $30 \mathrm{~min}$ with PBS containing $2 \%(\mathrm{vol} / \mathrm{vol})$ cow's milk as a blocking step. After washing, biotinylated purified mAb C8.6 was added (final concentration 0.25 $\mu \mathrm{g} / \mathrm{ml}$ ) together with IL-12 containing samples diluted in high-performance ELISA buffer (CLB, Amsterdam, The Netherlands) for $1.5 \mathrm{~h}$. Thereafter, the plates were washed five times and incubated with poly-streptavidin-horseradish peroxidase (CLB), 1:10,000 diluted (according to the manufacturer's instructions) in PBS containing $2 \%$ (vol/vol) cow's milk for $0.5 \mathrm{~h}$, washed, and developed with a solution of $100 \mu \mathrm{g} / \mathrm{ml}$ of 3,5,3',5'-tetramethylbenzidine (Merck, Darmstadt, Germany) with $0.003 \%$ (vol $/ \mathrm{vol}) \mathrm{H}_{2} \mathrm{O}_{2}$ in $0.11 \mathrm{M}$ sodium acetate, $\mathrm{pH}$ $5.5(100 \mu \mathrm{l} /$ well $)$. The reaction was stopped by adding an equal volume of $2 \mathrm{M} \mathrm{H}_{2} \mathrm{SO}_{4}$ to the wells. Plates were read at $450 \mathrm{~nm}$ in a Titertek Multiskan reader. Background absorbance at $540 \mathrm{~nm}$ was subtracted. rhIL-12 p70, provided by Dr. S.F. Wolf (Genetics Institute Inc., Cambridge, MA), was used as a standard and the detection limit was $0.5 \mathrm{pg} / \mathrm{ml}$ (twice the background). This assay does not detect free p40 (provided by Dr. S.F. Wolf, Genetics Institute, Inc.) up to $20 \mathrm{ng} / \mathrm{ml}$.

IL-12 ELISA. IL-12 ELISA detects both p40 and p70 (20) and was performed identical to the p70-specific ELISA with the exception that the coating antibody was replaced by $\mathrm{mAb} \mathrm{C} 11.79$, which was used at $2 \mu \mathrm{g} / \mathrm{ml}$. IL-12 containing culture supernatant, standardized to rhIL-12 p70 (provided by Dr. S.F. Wolf, Genetics Institute,
Inc.), was used as a standard. The detection limit was $4 \mathrm{pg} / \mathrm{ml}$ (twice the background).

IL-10 ELISA. IL-10 ELISA assay was performed identical to the IL-12 ELISA, except that the blocking step was omitted (20). For coating, $\mathrm{mAb}$ B-N10 was used at $0.5 \mu \mathrm{g} / \mathrm{ml}$ in PBS, and for detection, biotinylated mAb B-T10 was used at $0.125 \mu \mathrm{g} / \mathrm{ml}$. rhIL-10 was used as a standard.

IL-6 ELISA. Procedures were identical to the IL-12 ELISA, except that the blocking step was eliminated and for coating anti-IL-6, $\mathrm{mAb}$ CLB.IL6/16 was used at $1 \mu \mathrm{g} / \mathrm{ml}$ in PBS. Affinity-purified biotinylated polyclonal sheep anti-IL-6 was used for detection at $0.25 \mu \mathrm{g} /$ $\mathrm{ml}$ (33). rhIL-6 (34) was used as a standard. The detection limit was 1 $\mathrm{pg} / \mathrm{ml}$.

\section{Competitive reverse transcriptase ( $R T)-P C R$}

Whole blood (see above) was stimulated with SAC in the absence or presence of $10 \mathrm{ng} / \mathrm{ml}$ IFN- $\gamma$ (Boehringer Mannheim, Almere, The Netherlands). Total cellular RNA was extracted using TRIzol Reagent (GIBCO BRL/Life Technologies, Gaithersburg, MD) according to manufacturer's instructions. After determination of $\mathrm{A}_{260}$ and $\mathrm{A}_{280}, 1 \mu \mathrm{g}$ of RNA was transcribed to cDNA for $1 \mathrm{~h}$ at $37^{\circ} \mathrm{C}$ in $20-\mu \mathrm{l}$ reaction volumes containing $1 \times \mathrm{RT}$ buffer, $200 \mathrm{U}$ of Superscript RT (GIBCO BRL), oligo(dT) primer (GIBCO BRL), $0.01 \mathrm{M}$ dithiothreitol, and $0.5 \mathrm{mM}$ dNTP's (Promega, Madison, WI). The reaction was terminated by a 10 -min incubation at $95^{\circ} \mathrm{C}$.

Cellular cDNA was amplified together with twofold diluted titrations of an internal competitive standard of plasmid IL-12 and $\beta 2$ microglobulin $(\beta 2-\mathrm{M}) \mathrm{cDNA}$, pQB3, a kind gift from D. Shire (Sanofi ELF Bio Recherches, Labège, France) (35). The internal standard binds to the same primer set but yields a PCR product of a different length. PCR reactions were carried out in $1 \times$ PCR buffer supplemented with $1.5 \mathrm{mM} \mathrm{MgCl}, 0.2 \mathrm{mM}$ dNTP's, $750 \mathrm{nM}$ of each primer; for IL-12 p40: sense primer; ATTGAGGTCATGGTGGATGC, antisense primer; AATGCTGGCATTTTTGCGGC, and $\beta 2-\mathrm{M}$ : sense primer: CCAGCAGAGAATGGAAAGTC, antisense primer: GATGCTGCTTACATGTCTCG (GIBCO BRL), and $1.25 \mathrm{U}$ of Taq polymerase (GIBCO BRL) in a final volume of $25 \mu \mathrm{l}$. cDNA was denatured for $5 \mathrm{~min}$ at $95^{\circ} \mathrm{C}$, followed by 35 cycles of amplification: $95^{\circ} \mathrm{C}$ for $45 \mathrm{~s}, 59^{\circ} \mathrm{C}$ for $45 \mathrm{~s}$, and $72^{\circ} \mathrm{C}$ for $2 \mathrm{~min}$. After the last cycle, the samples were incubated at $72^{\circ} \mathrm{C}$ for $10 \mathrm{~min}$. The amplified products were separated by agarose gel electrophoresis in the presence of ethidium bromide and visualized by ultraviolet light to identify bands of equal intensity.

\section{Results}

Human IL-12 production is strongly reduced by histamine. Various bacterial stimuli induce cytokine production in whole blood cultures with different efficacies; both LPS, heat-killed Escherichia coli and formalin-fixed SAC lead to IL-12 p40 production, but only SAC leads to significant IL-12 p70 production $(14,36,37)$. Histamine, a mediator tightly connected to the effector phase of atopy, caused a strong reduction of IL-12 p40 and p70 production induced by SAC (Fig. 1). IL-12 p40 production induced by E. coli was inhibited to the same extend by histamine (not shown). In 15 donors, concentrations as low as $10^{-8} \mathrm{M}$ histamine led to a mean inhibition of IL-12 p70 production of more than $50 \%$ (Fig. 1). In the same cultures, production of IL-10 was approximately twofold enhanced in the presence of $10^{-7} \mathrm{M}$ histamine, whereas IL-6 production was not affected. To rule out the possibility that the effect of histamine on IL-12 is indirect via IL-10, we repeated the experiment in the presence of excess neutralizing antibodies to IL10. Fig. 2 shows that IL-10 is not involved in the inhibition of IL-12 production by histamine. 

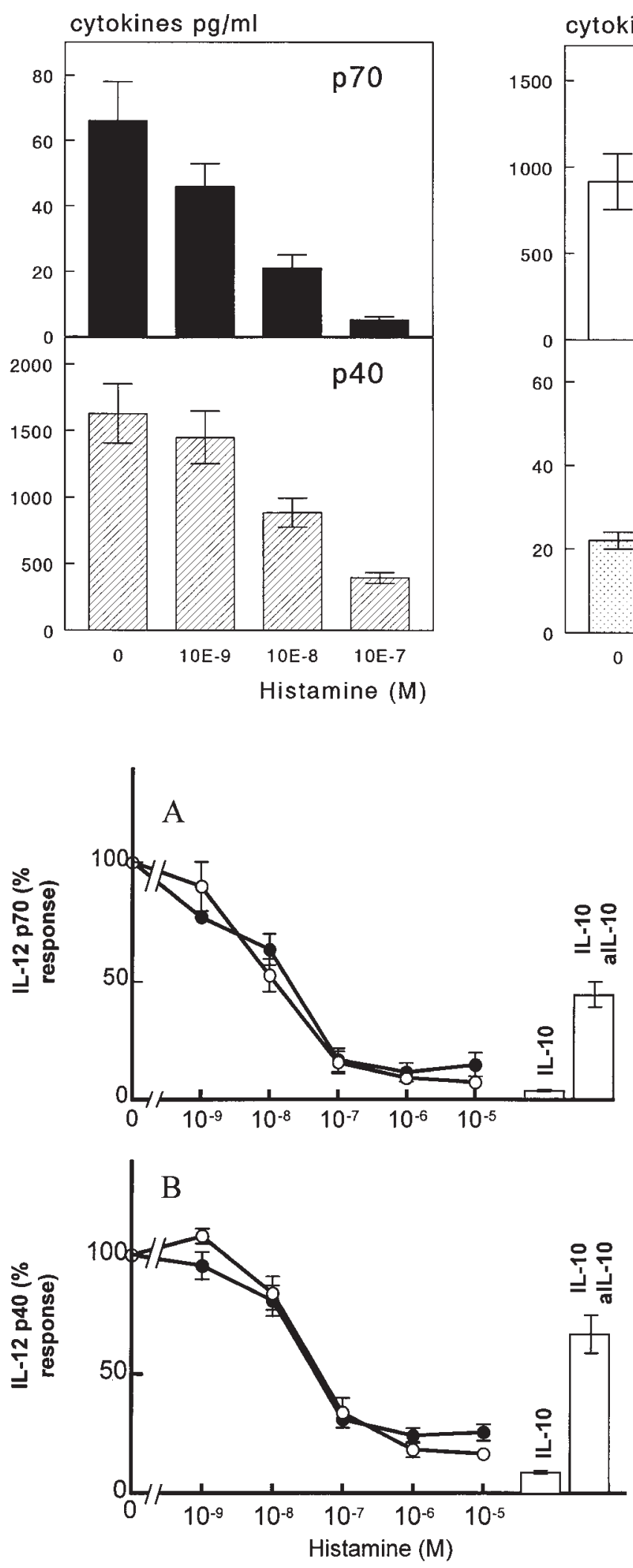

Figure 2. Inhibition of IL-12 p70 $(A)$ and p40 $(B)$ is independent of IL-10. Whole blood was stimulated with SAC in the absence $(O)$ or presence $(\bullet)$ of histamine and anti-IL-10. Anti-IL-10 mAb BT-10 was used at $5 \mu \mathrm{g} / \mathrm{ml}$, IL-10 at $600 \mathrm{pg} / \mathrm{ml}$. The results are the mean production $( \pm \mathrm{SE}$ ) of four donors. The mean IL-12 $\mathrm{p} 70$ and $\mathrm{p} 40$ production without addition of histamine or anti-IL-10 were $45 \mathrm{pg} / \mathrm{ml}$ and $1045 \mathrm{pg} / \mathrm{ml}$, respectively.

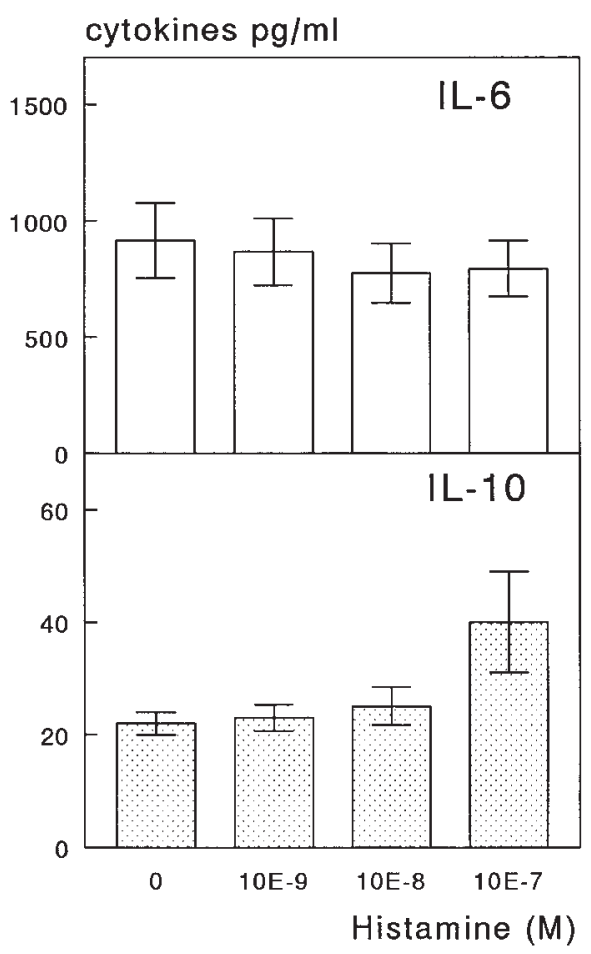

Figure 1. Effects of histamine on IL-12 p40 and p70, IL-6, and IL-10 production. Whole blood (1:10 diluted) was stimulated with SAC in the absence or presence of indicated concentrations of histamine. Results are the mean cytokine production \pm SE of 15 donors (p40, p70, and IL-6), for IL-10 the mean of six donors \pm $\mathrm{SE}$ is shown.
Histamine inhibits IL-12 production at the level of $m R N A$ production. We studied the effect of histamine on IL-12 p40 mRNA production using a competitive RT-PCR. First, we examined the kinetics of IL-12 mRNA production. A 6-h stimulation (in the absence or presence of IFN- $\gamma$ ) turned out to be optimal for IL-12 mRNA production (data not shown). We subsequently analyzed the effect of histamine on the production of IL-12 p40 mRNA after a 6-h stimulation with SAC with or without IFN- $\gamma$ (Fig. 3). The amount of IL-12 p40 cDNA is expressed relative to the amount of $\beta 2$-microglobulin cDNA as a measure for the amount of mRNA isolated (Fig. $3 \mathrm{~B}$ ). The production of IL-12 p40 mRNA was reduced to $<10 \%$ by histamine, irrespective of the presence of IFN- $\gamma$. The reduction of IL-12 p40 mRNA was accompanied by an equal reduction in IL-12 p40 protein production (measured after $24 \mathrm{~h}$ of stimulation; Fig. $3 B$ ). The fact that this inhibition also occurred in the presence of IFN- $\gamma$ indicates that the inhibition of histamine is not indirect through an inhibitive effect on IFN- $\gamma$ production.

Histamine directly affects monocyte IL-12 production. We have shown before that in whole blood, IL-12 production is derived from monocytes $(20,37)$. It could be argued that the observed inhibition of IL-12 production by histamine in whole blood cultures is indirect through another cell type. Therefore, we examined the effect of histamine on purified monocytes. Because the production of IL-12 is very low in isolated monocytes (36), IFN- $\gamma$ was added as a costimulator of SAC or LPS. Under these conditions, histamine inhibited the production of IL-12 to a similar extent as was observed in whole blood cultures (data not shown). Therefore, we conclude that histamine targets the monocyte directly.

Histamine-induced inhibition of IL-12 production can be reversed by an $\mathrm{H}_{2}$ antagonist. Three different receptors, $\mathrm{H}_{1}, \mathrm{H}_{2}$, and $\mathrm{H}_{3}$, mediate the biological effects of histamine. We analyzed which receptor was involved in the inhibition of IL-12 production using specific receptor antagonists. Triprolidine,

1868 van der Pouw Kraan et al. 


$\begin{array}{llll}A & & & \\ \end{array}$

Figure 3. Inhibition of IL-12 $\mathrm{p} 40 \mathrm{mRNA}$ and protein by histamine. $(A)$ Whole blood was stimulated with: lane 1, SAC; lane 2, SAC and histamine $10^{-6} \mathrm{M}$; lane 3 , SAC and IFN- $\gamma$; lane 4, SAC, IFN- $\gamma$ and histamine $10^{-6} \mathrm{M}$. RT products of cellular IL-12 p40 and $\beta 2-\mathrm{M}$ mRNA were quantified by coamplification with graded amounts of standard cDNA. The upper band represents plasmid cDNA, and the lower band represents cellular cDNA. For $\beta 2-\mathrm{M}, 0.1 \mu \mathrm{l}$ of the RT product was used in each PCR reaction. For IL-12, the quantities of RT products were: lane $1,0.1 \mu \mathrm{l}$; lane 2, 0.2 $\mu \mathrm{l}$; lane $3,0.05 \mu \mathrm{l}$; and lane $4,0.1 \mu \mathrm{l}$ for the same standard cDNA titrations. (B) The amount of IL12 p40 mRNA is expressed relative to the amount of $\beta 2-\mathrm{M}$. The amount of IL-12 p40 protein is measured after $24 \mathrm{~h}$ of culture. Representative results of one out of three experiments are shown. ranitidine, and clobenpropit selectively compete with the activity of histamine on $\mathrm{H}_{1}, \mathrm{H}_{2}$, and $\mathrm{H}_{3}$ receptors, respectively (22). Their antagonistic capacities are expressed as $\mathrm{pA}_{2}$ values, i.e., the negative logarithm of the concentration required to get $50 \%$ reduction of the efficacy of histamine. For triprolidine, a $\mathrm{pA}_{2}$ value of 9.7 has been found, for ranitidine 7.2, and for clobenpropit 9.9 (22). For all three antagonists, we tested the effect of 100 -fold the $\mathrm{pA}_{2}$ value. Only ranitidine, the $\mathrm{H}_{2}$ antagonist, reversed the inhibition by histamine of IL-12 p40 as well as p70 production. Neither the $\mathrm{H}_{1}$ nor the $\mathrm{H}_{3}$ antagonist had any effect (Fig. 4, $A$ and $B$ ). More detailed analysis of the ranitidine effect (Fig. 4, $C$ and $D$ ) allowed calculation of the $\mathrm{pA}_{2}$ value for ranitidine in this system. The obtained $\mathrm{pA}_{2}$ values, 7.2 and 7.3 for $\mathrm{p} 70$ and $\mathrm{p} 40$, respectively, correspond to the reported histamine-antagonizing potency of ranitidine. In this respect, the $\mathrm{H}_{2}$ receptor on monocytes functions identically to $\mathrm{H}_{2}$ receptors on nonlymphoid cells and is responsible for the inhibition of IL-12 production by histamine.

Specific stimulation of histamine $\mathrm{H}_{2}$ receptors by an $\mathrm{H}_{2}$ agonist inhibits the production of IL-12. To confirm that the inhibition of IL-12 production was due to specific interaction of histamine with $\mathrm{H}_{2}$ receptors, we also examined the effect of amthamine, a specific $\mathrm{H}_{2}$ agonist. Amthamine has been described to be 1.6 times more potent than histamine on $\mathrm{H}_{2}$ receptors but to have hardly any activity on $\mathrm{H}_{1}$ and $\mathrm{H}_{3}$ receptors (22). This was confirmed in our experiments because the IC50 values for amthamine and histamine were $1.8 \times 10^{-8}$ and $5 \times$ $10^{-8}$ for $\mathrm{p} 40$ production and $1.4 \times 10^{-8}$ and $3.6 \times 10^{-8}$ for $\mathrm{p} 70$ production, respectively, in the same donors (Fig. 5). As expected, the inhibition of IL-12 production by amthamine (and histamine) could again be reversed by an excess of the $\mathrm{H}_{2}$ antagonist ranitidine.
Histamine and $P G E_{2}$ have additive effects on the inhibition of $I L-12$ production. The inhibitive activities of histamine and $\mathrm{PGE}_{2}$ on IL-12 production were compared and examined for possible synergistic effects (Fig. 6). $\mathrm{PGE}_{2}$ appeared to be more potent than histamine at $10^{-9}$ and $10^{-8} \mathrm{M}$ in inhibiting IL-12 production, but at $10^{-7} \mathrm{M}$ there was no difference in activity. The combination of histamine and $\mathrm{PGE}_{2}$ resulted in a cumulative effect on the inhibition of IL-12 production, without any synergism.

\section{Discussion}

The present data indicate that histamine is an important inhibitor of the production of IL-12 by monocytes. Although SAC is an activator of both $\mathrm{B}$ cells and monocytes, B cells hardly contribute to the production of IL-12 (38). In whole blood cultures, monocytes are considered the main IL-12- and IL-6producing cells, because CD14-depleted MNC or granulocytes did not produce IL-12 or IL-6 after stimulation with SAC. In agreement with a direct inhibitive effect of histamine on the production of TNF- $\alpha$ and IL-1 in isolated monocytes $(28,29)$, we also observed an inhibition of IL-12 production by histamine in isolated monocytes, which could be reversed by an $\mathrm{H}_{2}$ antagonist (data not shown).

$\mathrm{PGE}_{2}$ (after interaction with the $\mathrm{PGE}_{2}$ receptor) and histamine (through interaction with the $\mathrm{H}_{2}$ receptor) activate adenylate cyclase, which leads to the generation of increased levels of cAMP in various cell types $(22,23)$. In previous reports, we showed that the effects of PGE 2 on IL-12 p40, TNF- $\alpha$, and IL-10 production by LPS-stimulated human monocytes in whole blood cultures could all be mimicked by cAMP $(20,36)$. In agreement with others (39), we observed increased levels of 

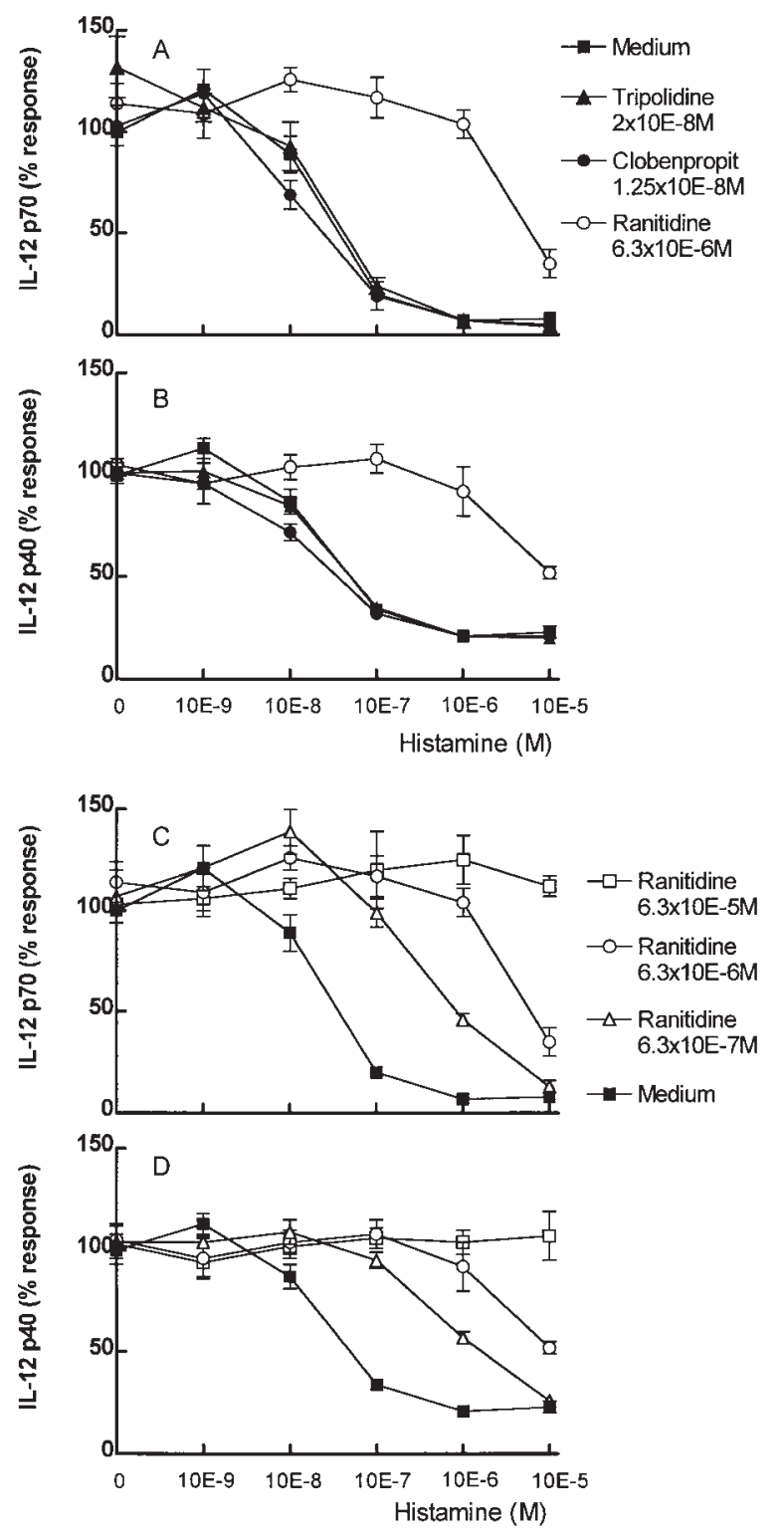

Figure 4. Reversal of histamine-induced inhibition of IL-12 production by a $\mathrm{H}_{2}$ antagonist. Whole blood (1:10 diluted) was stimulated with SAC and graded concentrations of histamine, in the absence or presence of different histamine antagonists as indicated. ( $A$ and $B$ ) Ranitidine $\left(\mathrm{H}_{2}\right.$ antagonist, $\mathrm{pA}_{2}$ 7.2), triprolidine $\left(\mathrm{H}_{1}\right.$ antagonist, $\mathrm{pA}_{2}=$ 9.7), and clobenpropit $\left(\mathrm{H}_{3}\right.$ antagonist, $\left.\mathrm{pA}_{2}=9.9\right)$ were all tested at 100 -fold the $\mathrm{pA}_{2}$ value. ( $C$ and $D$ ) Ranitidine was used at 10-, 100-, and 1,000-fold its $\mathrm{pA}_{2}$ value. Results are the mean production of four donors \pm SE. In the absence of histamine or antagonists, mean p70 production was $83 \mathrm{pg} / \mathrm{ml}$, and mean $\mathrm{p} 40$ production was $1,696 \mathrm{pg} / \mathrm{ml}$.

cAMP in purified monocytes after incubation with histamine, which could be prevented by an $\mathrm{H}_{2}$ antagonist (data not shown). Because both the inhibition of IL-12 production and enhancement of cAMP levels by histamine were mediated through the $\mathrm{H}_{2}$ receptor and the combined effects of histamine and $\mathrm{PGE}_{2}$ on IL-12 production were additive, histamine and $\mathrm{PGE}_{2}$ most likely inhibit IL-12 production by a similar cAMPdependent mechanism. The exact pathway of cAMP-induced inhibition of IL-12 production is presently unknown. In T cells, a cAMP-inducible transcriptional repressor protein (ICER, in-

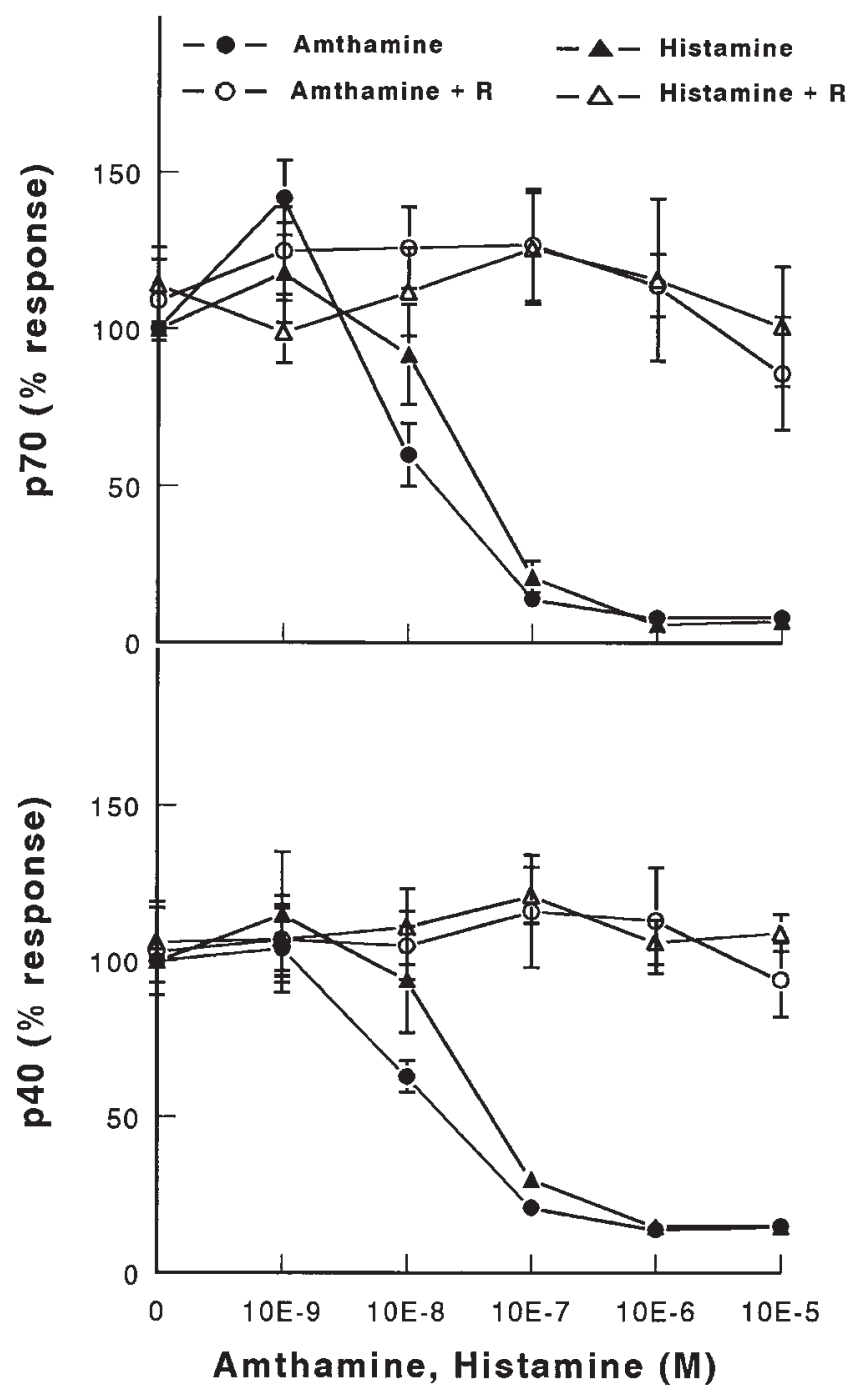

Figure 5. Inhibition of IL-12 production by the $\mathrm{H}_{2}$ agonist amthamine in comparison with histamine. Whole blood (1:10 diluted) was stimulated with SAC and the indicated concentrations of amthamine and histamine. The $\mathrm{H}_{2}$ antagonist ranitidine $(R)$ was used at $10^{-4} \mathrm{M}$. Results are the mean production of four donors \pm SE. In the absence of histamine or agonists/antagonists, mean IL-12 p70 and p40 production were $108 \mathrm{pg} / \mathrm{ml}$ and $2,023 \mathrm{pg} / \mathrm{ml}$, respectively.

ducible cAMP early repressor) has been described that inhibits IL-2 promoter activity (40). This mechanism probably involves binding of ICER to cAMP responsive elements (CRE), thereby inhibiting transactivating CRE-binding proteins. A similar mechanism may be responsible for the cAMP-induced inhibition of IL-12 production, since the human IL-12 p40 promoter contains a CRE-like motif (15). Another explanation may be reduced activation of NF- $\mathrm{B}$ through $\mathrm{cAMP}$-induced retardation of degradation of the inhibitor of $\mathrm{NF}-\kappa \mathrm{B}, \mathrm{I} \kappa \mathrm{B} \alpha$ (41). Murine p40 transcription has been shown to be positively regulated by NF-кB (42). Because the human IL-12 p40 promoter contains a NF-кB site (15), this may also be true for human $\mathrm{p} 40$ regulation.

Interestingly, both $\mathrm{PGE}_{2}$ and histamine are associated with Th2-mediated (allergic) diseases. Histamine is released during allergic reactions after interaction of allergens with cell-bound $\mathrm{IgE}$ on basophils and mast cells. $\mathrm{PGE}_{2}$ is overproduced by 


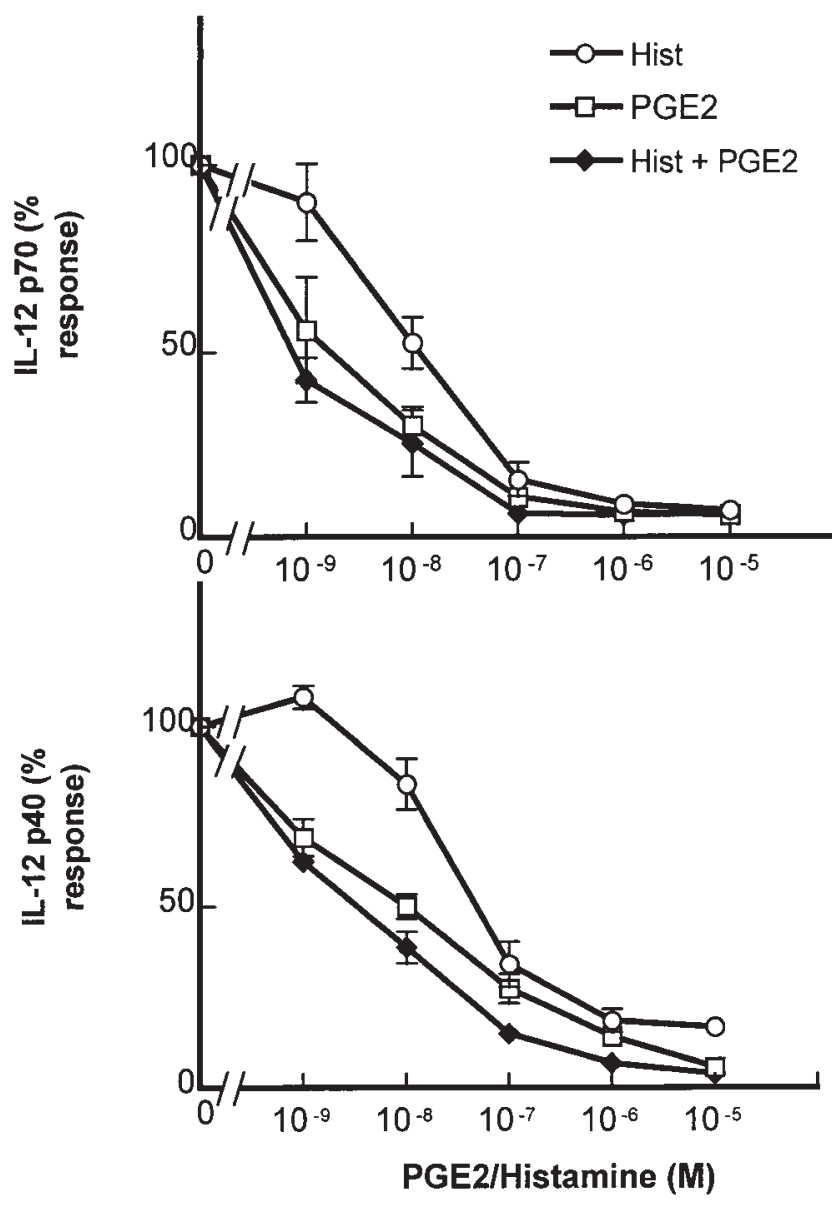

Figure 6. Histamine- and $\mathrm{PGE}_{2}$-induced inhibition of IL-12 production are additive. SAC-stimulated whole blood cultures were incubated with indicated concentrations of histamine and $\mathrm{PGE}_{2}$. Results are the mean production $( \pm \mathrm{SE})$ of four donors. Mean IL-12 p70 and $\mathrm{p} 40$ production without histamine or $\mathrm{PGE}_{2}$ were $45 \mathrm{pg} / \mathrm{ml}$ and 1,045 $\mathrm{pg} / \mathrm{ml}$, respectively.

PBMCs from atopic dermatitis and hyper-IgE patients (43, 44). In addition, PBMCs from atopic dermatitis patients show enhanced basal activation of PKA and increased levels of cAMP (45). In allergic asthma patients with enhanced IgE levels, we found a reduced capacity to produce IL-12 p70 in response to SAC (37). The in vivo exposure of monocytes to histamine and $\mathrm{PGE}_{2}$ could have contributed to this. Similar observations were reported on HIV-infected patients. A reduced production of IL-12 and an enhanced production of $\mathrm{PGE}_{2}$ (46-48) by PBMCs from these patients was observed. However, even after stimulation conditions with normal production of $\mathrm{PGE}_{2}$ or after blockage of the production of $\mathrm{PGE}_{2}$, the production of IL-12 is reduced in these patients $(49,50)$. Because HIV infection is accompanied by increased serum levels of $\mathrm{PGE}_{2}$ (51) and enhanced levels of intracellular cAMP and basal PKA activation (52), the in vivo production of $\mathrm{PGE}_{2}$ by other cell types or other cAMP-inducing agents such as histamine or $\beta$-adrenergic agonists may be responsible for the reduced production of IL-12. Although the role of histamine in HIV infection seems far fetched, treatment of AIDS related complex patients with an $\mathrm{H}_{2}$ antagonist has been claimed to yield beneficial effects, including improved $\mathrm{T}$ cell proliferation and delayed-type of hypersensitivity (DTH) reactions (53).
Also in mice the suppression of DTH responses caused by histamine can be reversed by $\mathrm{H}_{2}$ antagonists $(54,55)$. The in vivo role of histamine has also been investigated in allergic rhinitis patients. The systemic or local use of a histamine $\mathrm{H}_{2}$ antagonist decreases the levels of IgE in serum or nasal fluid, respectively $(56,57)$. Because $\mathrm{IgE}$ production can be considered a readout for Th2 responses, while Th1 responses are characterized by DTH responses, histamine is clearly positively influencing Th2 responses in vivo.

Overproduction of histamineand $\mathrm{PGE}_{2}$ can lead to Th2 responses by several mechanisms. Histamine $\left(\mathrm{H}_{2}\right.$ receptormediated) inhibits TNF- $\alpha$ production by monocytes (28), while $\mathrm{PGE}_{2}$ and other cAMP inducers have also been reported to inhibit TNF- $\alpha$ and to enhance IL-10 production by monocytes (20, $58,59)$. TNF- $\alpha$ may contribute to Th1 development by potentiating IL-12-induced production of IFN- $\gamma$ in PBMCs (16). In addition, cAMP, histamine, and $\mathrm{PGE}_{2}$ inhibit secretion of the Th1 cytokines IL- 2 and IFN- $\gamma$ but not the Th2 cytokines IL-4 and IL-5 (27, 60, 61). However, the most important mechanism of induction of Th2 development is probably the inhibition of IL-12 production, because the concentrations of $\mathrm{PGE}_{2}$ and histamine that inhibit the production of IL-12 are approximately 100- and 1000-fold lower, respectively, than those required for inhibition of $\mathrm{T}$ cell cytokine production. The levels of histamine that completely inhibit the production of IL-12 are well within the physiological range. Histamine reaches levels as high as $10^{-7} \mathrm{M}$ in serum or nasal washing fluids $(62,63)$, suggesting that concentrations of histamine in tissue may even be higher. Initial histamine release is dependent on the presence of $\mathrm{IgE}$, induced by Th2 cytokine production. Histamine may provide a positive feedback on continued Th2 differentiation by the inhibition of IL-12. In addition, histamine enhances anti-CD58 plus IL-4- or IL-13-induced IgE production in purified B cells (64). Interestingly, a positive feedback loop of histamine on Th2 differentiation appears to be more evident in allergic patients. Basophils from allergic asthma and atopic dermatitis patients show an increased histamine releasability compared with basophils from normal controls (65-67). This may lead to reduced IL-12 production and Th2 development, and as a result continued overproduction of IgE, a characteristic of these patients.

The observation that the cAMP/PKA pathway (possibly induced by histamine or $\mathrm{PGE}_{2}$ ) is overactive in a number of pathological conditions such as HIV infection and atopic diseases may lead to new intervention strategies designed to upregulate IL-12 production. The use of inhibitors of $\mathrm{PGE}_{2}$ synthesis and histamine $\mathrm{H}_{2}$ antagonists may be valuable to redirect $\mathrm{Th} 2$ to $\mathrm{Th} 0 / \mathrm{Th} 1$ responses in these conditions and may be combined with vaccination or hyposensitization therapy.

\section{Acknowledgments}

We thank G. Trinchieri and M.K. Gately for the IL-12 antibodies, S.F. Wolf for IL-12, R. de Waal Malefijt for IL-10, J. Wijdenes for the IL-10 antibodies, and C.P. de Ruig for helpful suggestions.

This work is financially supported by The Dutch Asthma Foundation. The research of R. Leurs was supported by The Royal Netherlands Academy of Arts and Sciences.

\section{References}

1. Mosmann, T.R., and R.L. Coffman. 1989. TH1 and TH2 cells: Different patterns of lymphokine secretion lead to different functional properties. Annu. Rev. Immunol. 7:145-173. 
2. Wierenga, E.A., M. Snoek, C. De Groot, I. Chretien, J.D. Bos, H.M. Jansen, and M.L. Kapsenberg. 1990. Evidence for compartmentalization of functional subsets of $\mathrm{CD}^{+}{ }^{+} \mathrm{T}$ lymphocytes in atopic patients. J. Immunol. 144:46514656.

3. Punnonen, J., G. Aversa, B.G. Cocks, A.N.J. McKenzie, S. Menon, G. Zurawski, R. De Waal Malefijt, and J.E. De Vries. 1993. Interleukin 13 induces interleukin 4-independent IgG4 and IgE synthesis and CD23 expression by human B cells. Proc. Natl. Acad. Sci. USA. 90:3730-3734.

4. Clerici, M. F.T. Hakim, D.J. Venzon, S. Blatt, C.W. Hendrix, T.A. Wynn, and G.M. Shearer. 1993. Changes in interleukin-2 and interleukin-4 production in asymptomatic, Human Immunodeficiency Virus-seropositive individuals. J. Clin. Invest. 91:759-765.

5. Kapsenberg, M.L., H.M. Jansen, J.D. Bos, and E.A. Wierenga. 1992. Role of type 1 and type $2 \mathrm{~T}$ helper cells in allergic disease. Curr. Opin. Immunol. 4:788-793.

6. Meyaard, L., S.A. Otto, I.P.M. Keet, R.A.W. Van Lier, and F. Miedema. 1994. Changes in cytokine secretion patterns of CD4+ T cell clones in HIV infection. Blood. 84:4262-4268.

7. O'Garra, A., and K. Murphy. 1993. T-cell subsets in autoimmunity. Curr. Opin. Immunol. 5:880-886.

8. Hsieh, C.S., S.E. Macatonia, C.S. Tripp, S.F. Wolf, A. O'Carra, and K.M. Murphy. 1993. Development of Th1 CD4 ${ }^{+}$T cells through IL-12 produced by Listeria-induced macrophages. Science. 260:547-549.

9. Trinchieri, G. 1994. Interleukin-12: a cytokine produced by antigen-presenting cells with immunoregulatory functions in the generation of T-helper cells type 1 and cytotoxic lymphocytes. Blood. 84:4008-4027.

10. Gately, M.K., B.B. Desai, A.G. Wolitzki, P.M. Quinn, C.M. Dwyer, F.J. Podlaski, P.C. Familletti, F. Sinigaglia, R. Chizonnite, U. Gubler, and A.S. Stern. 1991. Regulation of human lymphocyte proliferation by a heterodimeric cytokine, IL-12 (cytotoxic lymphocyte maturation factor). J. Immunol. 147:874882.

11. Wolf, S.F., P.A. Temple, M. Kobayashi, D. Young, M. Dicig, L. Lowe, R. Dzialo, L. Fitz, C. Ferenz, R.M. Hewick, K. Kelleher, S.H. Herrmann, S.C. Clark, L. Azzoni, S.H. Chan, G. Trinchieri, and B. Perussia. 1991. Cloning of cDNA for natural killer cell stimulatory factor, a heterodimeric cytokine with multiple biologic effects on T and natural killer cells. J. Immunol. 146:30743081.

12. Scharton-Kersten, T., L.C.C. Afonso, M. Wysocka, G. Trinchieri, and P. Scott. 1995. IL-12 is required for natural killer cell activation and subsequent $T$ helper 1 cell development in experimental Leishmaniasis. J. Immunol. 154: 5320-5330.

13. Hayes, M.P., J. Wang, and M.A. Norcross. 1995. Regulation of interleukin-12 expression in human monocytes: selective priming by interferon- $\tau$ of lipopolysaccharide-inducible p35 and p40 genes. Blood. 86:646-650.

14. Snijders, A., C.M.U. Hilkens, T.C.T.M. van der Pouw Kraan, M. Engel, L.A. Aarden, and M.L. Kapsenberg. 1996. Regulation of bioactive IL-12 production in lipopolysaccharide-stimulated human monocytes is determined by the expression of the p35 subunit. J. Immunol. 156:1207-1212.

15. Ma, X., J.M. Chow, G. Gri, G. Carra, F. Gerosa, S.F. Wolf, R. Dzialo, and G. Trinchieri. 1996. The interleukin 12 p40 gene promoter is primed by interferon $\tau$ in monocytic cells. J. Exp. Med. 183:147-157.

16. D'Andrea, A., M. Aste-Amezaga, N.M. Valiante, X. Ma, M. Kubin, and G. Trinchieri. 1993. Interleukin 10 (IL-10) inhibits human lymphocyte interferon-gamma-production by suppressing natural killer cell stimulatory factor/ IL-12 synthesis in accessory cells. J. Exp. Med. 178:1041-1048.

17. D'Andrea, A., X. Ma, M. Aste-Amezaga, C. Paganin, and G. Trinchieri. 1995. Stimulatory and inhibitory effects of interleukin (IL)-4 and IL-13 on the production of cytokines by human peripheral blood mononuclear cells: priming for IL-12 and tumor necrosis factor $\alpha$ production. J. Exp. Med. 181:537-546.

18. Marth, T., and B.L. Kelsall. 1997. Regulation of interleukin-12 by complement receptor 3 signaling. J. Exp. Med. 185:1987-1995.

19. Karp, C.L., M. Wysocka, L.M. Wahl, J.M. Ahearn, P.J. Cuomo, B. Sherry, G. Trinchieri, and D.E. Griffin. 1996. Mechanism of suppression of cellmediated immunity by measles virus. Science. 273:228-231.

20. van der Pouw Kraan, T.C.T.M., L.C.M. Boeije, R.J.T. Smeenk, J. Wijdenes, and L.A. Aarden. 1995. Prostaglandin- $E_{2}$ is a potent inhibitor of human interleukin 12 production. J. Exp. Med. 181:775-779.

21. Panina-Bordignon, P., D. Mazzeo, P. Di Lucia, D. D'Ambrosio, R. Lang, L. Fabbri, C. Self, and F. Sinigaglia. 1997. $\beta 2$-agonists prevent Th1 development by selective inhibition of IL-12. J. Clin. Invest. 100:1513-1519.

22. Leurs, R., M.J. Smit, and H. Timmerman. 1995. Molecular pharmacological aspects of histamine receptors. Pharmacol. Ther. 66:413-463.

23. Hill, S.J. 1990. Distribution, properties, and functional characteristics of three classes of histamine receptor. Pharmacol. Rev. 42:45-83.

24. Smit, M.J., R. Leurs, S.R. Shukrula, A. Bast, and H. Timmerman. 1994. Rapid desensitisation of the histamine $\mathrm{H} 2$ receptor on the human monocytic cell line U937. Eur. J. Pharmacol. 288:17-25.

25. Cameron, W., K. Doyle, and R.E. Rocklin. 1986. Histamine type 1 (H1) receptor radioligand binding studies on normal $\mathrm{T}$ cell subsets, $\mathrm{B}$ cells, and monocytes. J. Immunol. 136:2116-2120.

26. Beer, D.J., S.M. Matloff, and R.E. Rocklin. 1984. The influence of histamine on immune and inflammatory responses. Adv. Immunol. 35:209-268.
27. Dohlsten, M., H.O. Sjögren, and R. Carlsson. 1987. Histamine acts directly on human $\mathrm{T}$ cells to inhibit interleukin-2 and interferon- $\tau$ production. Cell. Immunol. 109:65-74.

28. Vannier, E., L.C. Miller, and C.A. Dinarello. 1991. Histamine suppresses gene expression and synthesis of tumor necrosis factor $\alpha$ via histamine H2 receptors. J. Exp. Med. 174:281-284.

29. Dohlsten, M., T. Kalland, H.O. Sjögren, and R. Carlsson. 1988. Histamine inhibits interleukin 1 production by lipopolysaccharide-stimulated human peripheral blood monocytes. Scand. J. Immunol. 27:527-532.

30. Raible, D.G., E.S. Schulman, J. Dimuzio, R. Cardillo, and T.J. Post. 1992. Mast cell mediators prostaglandin-D2 and histamine activate human eosinophils. J. Immunol. 148:3536-3542.

31. D'Andrea, A., M. Rengaraju, N.M. Valiante, J. Chehimi, M. Kubin, M. Aste, S. Chan, M. Kobayashi, D. Young, E. Nickbarg, R. Chizzonite, S.F. Wolf, and G. Trinchieri. 1992. Production of natural killer cell stimulatory factor (interleukin 12) by peripheral blood mononuclear cells. J. Exp. Med. 176:13871398.

32. Schindler, R., and C.A. Dinarello. 1989. A method for removing interleukin-1- and tumor necrosis factor-inducing substances from bacterial cultures by ultrafiltration with polysulfone. J. Immunol. Methods. 116:159-165.

33. Helle, M. L. Boeije, E.R. De Groot, A. De Vos, and L.A. Aarden. 1991. Sensitive ELISA for interleukin 6. Detection of IL-6 in biological fluids: synovial fluids and sera. J. Immunol. Methods. 138:47.

34. Aarden, L.A., E.R. De Groot, O.L. Schaap, and P.M. Lansdorp. 1987. Production of hybridoma growth factor by human monocytes. Eur. J. Immunol. 17:1411-1416

35. Bouaboula, M., P. Legoux, B. Pess'gu, B. Delpech, X. Dumont, M. Piechaczyk, P. Casellas, and D. Shire. 1992. Standardization of mRNA titration using a polymerase chain reaction method involving co-amplification with a multispecific internal control. J. Biol. Chem. 267:21830-21838.

36. van der Pouw Kraan, T.C.T.M., L.C.M. Boeije, A. Snijders, R.J.T. Smeenk, J. Wijdenes, and L.A. Aarden. 1996. Regulation of IL-12 production by human monocytes and the influence of prostaglandin $\mathrm{E}_{2}$. Ann. N.Y. Acad. Sci. 795:147-157.

37. van der Pouw Kraan, T.C.T.M., L.C.M. Boeije, E.R. De Groot, S.O. Stapel, A. Snijders, M.L. Kapsenberg, J.S. van der Zee, and L.A. Aarden. 1997. Reduced production of interleukin 12 (IL-12) and IL-12-dependent IFNgamma release by allergic asthma patients. J. Immunol. 158:5560-5565.

38. Ma, X., A. D'Andrea, M. Kubin, M. Aste-Amezaga, A. Sartori, J. Monteiro, L. Showe, M. Wysocka, and G. Trinchieri. 1995. Production of interleukin-12. Res. Immunol. 146:432-438.

39. Coffey, R.G., V.A. Alberts, and L.L. Weakland. 1990. Prostaglandindependent desensitization of human monocyte cAMP responses. J. Leukocyte Biol. 48:557-564.

40. Bodor, J., A. Spetz, J.L. Strominger, and J.F. Habener. 1996. cAMP inducibility of transcriptional repressor ICER in developing and mature T lymphocytes. Proc. Natl. Acad. Sci. USA. 93:3536-3541.

41. Haraguchi, S., R.A. Good, and N.K. Day. 1995. Immunosuppressive retroviral peptides: cAMP and cytokine patterns. Immunol. Today. 16:595-603.

42. Murphy, T.L., M.G. Cleveland, P. Kulesza, J. Magram, and K.M. Murphy. 1995. Regulation of interleukin 12 p40 expression through an NF-kB halfsite. Mol. Cell. Biol. 15:5258-5267.

43. Jacob, T., B.N. Huspith, Y.E. Latchman, R. Rycroft, and J. Brostoff. 1990. Depressed lymphocyte transformation and the role of prostaglandins in atopic dermatitis. Clin. Exp. Immunol. 79:380-384.

44. Leung, D.Y.M., L. Key, J.J. Steinberg, M.C. Young, M. Von Deck, R. Wilkinson, and R.S. Geha. 1988. Increased in vitro bone resorption by monocytes in the hyper-immunoglobulin E syndrome. J. Immunol. 140:84-88.

45. Trask, D.M., S.C. Chan, S.E. Sherman, and J.M. Hanifin. 1988. Altered leukocyte protein kinase activity in atopic dermatitis. J. Invest. Dermatol. 90: 526-531.

46. Foley, P., F. Kazazi, R. Biti, T.C. Sorrell, and A.L. Cunningham. 1992. $\mathrm{HIV}$ infection of monocytes inhibits the T-lymphocyte proliferative response to recall antigens, via production of eicosanoids. Immunology. 75:391-397.

47. Mastino, A., S. Grelli, M. Piacentini, S. Oliverio, C. Favalli, C.F. Perno, and E. Garaci. 1993. Correlation between induction of lymphocyte apoptosis and prostaglandin $\mathrm{E}_{2}$ production by macrophages infected with HIV. Cell. Immunol. 152:120-130.

48. Chehimi, J., S.E. Starr, I. Frank, A. D'Andrea, X. Ma, R.R. MacGregor, J. Sennelier, and G. Trinchieri. 1994. Impaired interleukin-12 production in human immunodeficiency virus-infected patients. J. Exp. Med. 179:1361-1366.

49. Meyaard, L., E. Hovenkamp, N. Pakker, T.C.T.M. van der Pouw Kraan, and F. Miedema. 1997. Interleukin-12 (IL-12) production in whole blood cultures from Human Immunodeficiency Virus-infected individuals studied in relation to IL-10 and prostaglandin $\mathrm{E}_{2}$ production. Blood. 89:570-576.

50. Marshall, J.D., S.E. Robertson, G. Trinchieri, and J. Chehimi. 1997. Priming with IL-4 and IL-13 during HIV-1 infection restores in vitro IL-12 production by mononuclear cells of HIV-infected patients. J. Immunol. 159:5705-5714.

51. Delemarre, F.G.A., A. Stevenhagen, F.P. Kroon, M.Y. van Eer, P.L. Meenhorst, and R. van Furth. 1995. Reduced toxoplasmastatic activity of monocytes and monocyte-derived macrophages from AIDS patients is mediated via prostaglandin E2. AIDS. 9:441-445. 
52. Hofmann, B., P. Nishanian, T. Nguyen, M. Liu, and J.L. Fahey. 1993. Restoration of T-cell function in HIV infection by reduction of intracellular cAMP levels with adenosine analogues. AIDS. 7:659-664.

53. Brockmeyer, N.H., E. Kreuzfelder, L. Mertins, N. Chalabi, W. Kirch, N. Scheiermann, M. Goos, and E.E. Ohnhaus. 1988. Immunomodulatory properties of cimetidine in ARC patients. Clin. Immunol. Immunopathol. 48:50-60.

54. Tasaka, K., K. Kurokawa, Y. Nakayama, and M. Kakimoto. 1986. Effect of histamine on delayed-type hypersensitivity in mice. Immunopharmacology. 12:69-77.

55. Ptak, W., G.P. Geba, and P.W. Askenase. 1991. Initiation of delayedtype hypersensitivity by low doses of monoclonal IgE antibody. Mediation by serotonin and inhibition by histamine. J. Immunol. 146:3929-3936.

56. Testa, B., F. Mazzel, M. Mesolella, A. Maione, D. Testa, and C. Mesolella. 1989. Histamine 2 antagonists in allergic rhinitis. Relationship of clinical response and serum concentrations of total and specific $\operatorname{IgE}$ antibody levels. Arch. Otolaryngol. Head Neck Surg. 115:950-953.

57. Yang, P.C., T. Liu, T.Y. Zhang, and D.S. Fan. 1997. The effect of the H2 antagonist cimetidine on the numbers of CD4+ and CD8+ cells in the nasal mucosa of patients with allergic rhinitis. Clin. Otolaryngol. 22:93-95.

58. Kunkel, S.L., M. Spengler, M.A. May, R. Spengler, J. Larrick, and D. Remick. 1988. Prostaglandin $\mathrm{E}_{2}$ regulates macrophage-derived tumor necrosis factor gene expression. J. Biol. Chem. 263:5380-5384.

59. Strassmann, G., V. Patil-Koota, F. Finkelman, M. Fong, and T. Kambayashi. 1994. Evidence for the involvement of interleukin 10 in the differential deactivation of murine peritoneal macrophages by prostaglandin E2. J. Exp. Med. 180:2365-2370.
60. Snijdewint, F.G.M., P. Kalinski, E.A. Wierenga, J.D. Bos, and M.L. Kapsenberg. 1993. Prostaglandin $\mathrm{E}_{2}$ differentially modulates cytokine secretion profiles of human T helper lymphocytes. J. Immunol. 150:5321-5329.

61. Van der Pouw Kraan, T., C. Van Kooten, H.J.A.M. Rensink, and L.A. Aarden. 1992. IL-4 production by human T cells. Differential regulation of IL-4 versus IL-2 production. Eur. J. Immunol. 22:1237-1241.

62. Naclerio, R.M., D. Proud, A.G. Togias, N.F. Adkinson, D.A. Meyers, A. Kagey-Sobotka, M. Plaut, P.S. Norman, and L.M. Lichtenstein. 1985. Inflammatory mediators in late antigen-induced rhinitis. N. Engl. J. Med. 313:6570.

63. Deyer, J., K. Warren, S. Merlin, D.D. Metcalfe, and M. Kaliner. 1982. Measurement of plasma histamine: description of an improved method and normal values. J. Allergy Clin. Immunol. 70:82-87.

64. Kimata, H., M. Fujimoto, C. Ishioka, and A. Yoshida. 1996. Histamine selectively enhances human immunoglobulin $\mathrm{E}(\mathrm{IgE})$ and $\mathrm{IgG} 4$ production induced by anti-CD58 monoclonal antibody. J. Exp. Med. 184:357-364.

65. Casolaro, V., G. Spadara, and G. Marone. 1990. Human basophil releasability VI. Changes in basophil releasability in patients with allergic rhinitis or bronchial asthma. Am. Rev. Respir. Dis. 142:1108-1111.

66. Gaddy, J.N., and W.W. Busse. 1986. Enhanced IgE-dependent basophil histamine release and airway reactivity in asthma. Am. Rev. Respir. Dis. 134: 969-974.

67. Marone, G., R. Giugliano, G. Lembo, and F. Ayala. 1986. Human basophil releasability. II. Changes in basophil releasability in patients with atopic dermatitis. J. Invest. Dermatol. 87:19-23. 